\title{
Kemampuan Kompos dan Kompos Plus untuk Meningkatkan Ketahanan Tanaman Tomat terhadap Penyakit Bercak Coklat (Alternaria solani Sor.)
}

\author{
Noor Istifadah ${ }^{1}$ dan Nasrul Hakim ${ }^{2}$ \\ ${ }^{1}$ Departemen Hama dan Penyakit Tumbuhan, Fakultas Pertanian, Universitas \\ Padjadjaran Kampus Jatinangor 45363 \\ ${ }^{2}$ Alumnus Program Studi Agroteknologi, Fakultas Pertanian, Universitas Padjadjaran \\ *Alamat korespondensi: n.istifadah@unpad.ac.id
}

\begin{abstract}
Abilities of compost and compost plus to enhance tomato resistance to early blight (Alternaria solani Sor.)

Compost can be used for organic fertilizer and also for disease control. To enhance its effectiveness, compost was fortified with antagonistic microbes and called compost plus. The aims of this study were to examine the potential of compost plus and its component, compost and antagonistic fungi (Trichoderma harzianum, Papulaspora sp. and Paecylomyces sp.) to enhance tomato resistance to early blight disease (Alternaria solanı) and also to obtain the effective and efficient application methods of compost plus for enhancing the plant resistance. The results showed that compos, compost plus and $T$. harzianum enhanced the tomato resistance so that suppressed early blight disease by $39.2 \%-40.1 \%$. The application methods were not significantly influenced the effectiveness of compost plus in enhancing the plant resistance. The application of compost plus as seed dressing, in the planting site or spraying water extract onto leaves solely or in combination suppress early blight disease by $31.96 \%-42.08 \%$. The separation between the treatments and pathogen inoculation indicated the increase or induction of tomato resistance to the disease.
\end{abstract}

Keywords: Antagonistic microbes, Trichoderma harzianum, Application method, Induced resistance

\begin{abstract}
ABSTRAK
Kompos selain dapat berfungsi sebagai pupuk organik juga dapat dimanfaatkan untuk pengendalian penyakit. Guna meningkatkan keefektifannya, kompos ditambah dengan jamur antagonis dan disebut 'kompos plus'. Penelitian ini bertujuan untuk menguji kemampuan kompos plus dan komponen penyusunnya yaitu kompos dan jamur antagonis (Trichoderma harzianum, Papulaspora sp. dan Paecylomyces sp.) untuk meningkatkan ketahanan tanaman tomat terhadap penyakit bercak coklat dan mendapatkan cara aplikasi kompos plus yang efektif dan efisien untuk meningkatkan ketahanan tanaman. Hasil percobaan menunjukkan bahwa kompos plus, kompos, dan T. harzianum dapat meningkatkan ketahanan tanaman tomat sehingga menekan penyakit bercak coklat sebesar 39,2\%-40,1\%. Cara aplikasi kompos plus tidak berpengaruh secara nyata terhadap kemampuannya dalam meningkatkan ketahanan tanaman. Aplikasi kompos plus dengan cara perendaman benih dalam air rendaman kompos plus, aplikasi pada lubang tanam atau penyemprotan dengan air rendaman kompos baik secara tunggal maupun dengan cara gabungan dapat menekan penyakit bercak coklat sebesar 31,96\%-42,08\%. Pemisahan tempat antara perlakuan dengan inokulasi patogen mengindikasikan adanya peningkatan atau induksi ketahanan tanaman terhadap penyakit.
\end{abstract}

Kata Kunci: Mikroba antagonis, Trichoderma harzianum, Cara aplikasi, Induksi ketahanan 


\section{PENDAHULUAN}

Tomat merupakan komoditas berpeluang ekspor yang banyak dibudidayakan di sentra-sentra hortikultura di Jawa Barat. Salah satu kendala utama dalam budidaya tomat adalah adanya penyakit bercak coklat yang disebabkan oleh Alternaria solani Sor. Patogen ini dapat menyerang daun, ranting, tangkai maupun buah tomat sehingga menyebabkan kerugian baik secara kuantitatif maupun kualitatif karena adanya buah-buah yang bergejala. Pada gejala lanjut, daun yang terinfeksi akan mengering dan buah yang terinfeksi akan rontok (Semangun, 2007).

Cara pengendalian penyakit yang umum digunakan adalah dengan penggunaan pestisida. Namun demikian, penggunaan pestisida yang kurang bijaksana dapat menimbulkan berbagai dampak negatif seperti resistensi patogen, pencemaran maupun residu pestisida pada produk pertanian yang berbahaya bagi kesehatan. Adanya kemungkinan dampak negatif dari pestisida dan meningkatnya permintaan akan produk pertanian yang bebas residu pestisida, telah memacu pengembangan cara pengendalian yang ramah lingkungan diantaranya adalah pengendalian secara biologi dan penggunaan bahan organik misalnya kompos.

Kemampuan kompos untuk menekan berbagai penyakit tular tanah telah banyak dikaji (Trillas et al., 2004; Noble \& Coventry, 2005; Aviles et al., 2011; St. Martin et al., 2012). Selain dapat mengendalikan berbagai penyakit tular tanah, kompos juga dapat menekan penyakit tular udara. Zhang et al. (1996) melaporkan bahwa kompos yang digunakan sebagai campuran medium tanam dapat menginduksi ketahanan tanaman mentimun terhadap penyakit jamur Colletotrichum arbicularea pada daun. Vallad et al. (2003) juga melaporkan bahwa aplikasi kompos dari limbah pabrik kertas pada medium tanam dapat menginduksi ketahanan tanaman Arabidopsis dan tomat sehingga menghambat perkembangan penyakit bacterial speck pada daun. Selain diaplikasikan dalam tanah, kompos dapat juga diaplikasikan dalam bentuk air rendamannya untuk mengendalikan penyakit tular udara (Scheuerell \& Mahaffee, 2002; Trillas et al, 2006; St Martin et al., 2012).

Secara umum efek pengendalian yang dihasilkan oleh penambahan bahan organik biasanya tidak konsisten (Hoitink et al., 1996; Noble \& Coventry, 2005). Penambahan agen antagonis yang telah diketahui keefektifannya ke dalam bahan organik dapat meningkatkan efek pengendalian dan konsistensinya (Hoitink et al., 1996; Postma et al., 2003; Pugliese et al., 2011).

Istifadah dkk. (2007) telah mengembangkan kompos yang ditambah mikroba antagonis (Trichoderma harzianum, Papulaspora sp. dan Paecylomyces sp.) yang disebut kompos plus. Pada penelitian sebelumnya, kompos plus ini telah diketahui dapat menekan penyakit tular tanah seperti rebah semai/damping-off pada tanaman tomat, sebesar 90,6\% (Istifadah dkk., 2007) dan penyakit layu fusarium pada tanaman tomat dengan tingkat penekanan sebesar $87,7 \%$ (Istifadah dkk., 2008).

Selain berpengaruh secara langsung, kompos plus ini juga diharapkan dapat meningkatkan ketahanan tanaman terhadap penyakit. Guna menginduksi ketahanan tanaman, bahan penginduksi biasanya dapat diaplikasikan untuk perlakuan benih, perendaman akar, aplikasi pada lubang tanam ataupun disemprotkan pada daun muda. Artikel ini mendiskusikan hasil penelitian yang mengevaluasi kemampuan kompos plus serta komponen penyusunnya yaitu kompos, dan mikroba antagonis untuk meningkatkan ketahanan tanaman tomat terhadap penyakit bercak coklat ( $A$. solani) pada tanaman tomat. Mengingat bahwa bahan penginduksi dapat diaplikasikan dengan beberapa cara, maka dalam artikel ini juga didiskusikan cara aplikasi kompos plus yang tepat agar efek dari peningkatan ketahanan tanaman dapat optimal.

\section{BAHAN DAN METODE}

Pengujian Kemampuan Kompos, Kompos Plus dan Jamur Antagonis untuk Meningkatkan Ketahanan Tanaman Tomat terhadap Penyakit Bercak Coklat $(A$. solani)

Percobaan ini ditujukan untuk mengevaluasi kemampuan kompos plus dan komponen penyusunnya untuk meningkatkan ketahanan tanaman tomat. Rancangan percobaan yang digunakan adalah Rancangan Acak Kelompok (RAK) dengan tujuh perlakuan dan empat ulangan. Perlakuan yang diuji antara lain kompos plus, kompos, T. harzianum, Papulaspora sp., Paecylomyces sp., campuran antagonis dan kontrol.

Kompos yang digunakan dalam percobaan ini adalah kompos berbahan dasar kotoran sapi. Kompos plus disiapkan menurut metode yang dikembangkan Istifadah dkk. (2007). Air rendaman kompos atau kompos plus dibuat dengan cara mencampurkan bahan dengan air sebanyak 20\% (v/v) kemudian disimpan dalam wadah tertutup dan 
diinkubasikan selama seminggu (Scheuerell \& Mahaffee, 2002). Setelah itu, air rendaman disaring dan digunakan untuk perlakuan perendaman benih dan penyemprotan daun.

Guna mendapatkan hasil yang maksimal, cara aplikasi yang digunakan adalah cara yang paling lengkap yaitu dengan perendaman benih menggunakan air rendaman kompos atau kompos plus atau suspensi konidia (kerapatan $10^{7}$ konidia/ml), pemberian perlakuan pada medium tanam dan penyemprotan daun pada semai. Aplikasi dengan cara perendaman benih dilakukan dengan merendam benih dalam suspensi kompos, kompos plus atau suspensi konidia jamur antagonis selama 30 menit. Benih yang sudah diberi perlakuan, kemudian ditanam pada seed tray. Untuk perlakuan pada medium tanam, kompos atau kompos plus dicampurkan ke dalam lubang tanam sebanyak $100 \mathrm{~g}$ pada saat pindah tanam. Suspensi konidia jamur masing-masing antagonis $\left(10^{7}\right.$ konidia/ml $)$ diaplikasikan sebanyak $50 \mathrm{ml}$ per lubang tanam. Untuk campuran antagonis, suspensi konidia $T$. harzianum, Papulaspora sp., dan Paecilomyces sp. dicampurkan (1:1:1, v/v) kemudian diaplikasikan sebanyak $50 \mathrm{ml} / \mathrm{lubang}$ tanam. Penyemprotan daun menggunakan air rendaman kompos atau kompos plus ataupun suspensi konidia antagonis dilakukan setelah semai tomat membentuk empat daun pertama.

Inokulasi patogen dilakukan dengan cara menempelkan potongan biakan $A$. solani berukuran diameter $0,5 \mathrm{~cm}$ pada permukaan daun muda (di atas daun yang diaplikasikan perlakuan sebelumnya). Potongan biakan tersebut ditutup menggunakan cling wrap dan untuk menjaga kelembabannya, tanaman disungkup dengan plastik selama 24 jam. Setelah 3 hari cling wrap dibuka dan diamati perkembangan gejalanya.

Perkembangan penyakit diamati dengan cara mengukur diameter bercak setiap tiga hari sekali. Data tersebut digunakan untuk menghitung luas daerah dibawah kurva (Area Under Disease Progres Curve, AUDPC). Rumus AUDPC (Campbell \& Madden, 1990) adalah:

$$
\text { AUDPC }=\sum_{i=l}^{n=1} \frac{Y_{i+1}+Y_{i}}{2}\left[t_{i+1}-t_{i}\right]
$$

Keterangan:

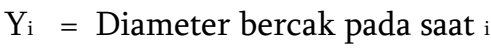

$\mathrm{Y}_{\mathrm{i}+1}=$ Diameter bercak pada saat ${ }_{i+1}$

$\mathrm{t}_{\mathrm{i}}$ = Beda waktu antar pengamatan

$\mathrm{t}_{\mathrm{i}+1}=\mathrm{Waktu}$ pengamatan saat $\mathrm{i}_{\mathrm{i}}$
Selain perkembangan penyakit, efek perlakuan terhadap pertumbuhan tanaman juga diamati. Agar kemampuan untuk memacu pertumbuhan dapat diketahui tanpa adanya pengaruh dari keberadaan penyakit, maka pengamatan pertumbuhan (tinggi tanaman) hanya dilakukan pada saat di persemaian sebelum tanaman diinokulasi patogen.

\section{Pengujian Cara Aplikasi Kompos Plus}

Percobaan ini dilakukan untuk mendapatkan cara aplikasi kompos plus yang paling baik dan efisien dalam meningkatkan ketahanan tanaman. Percobaan dilakukan menggunakan Rancangan Acak Kelompok (RAK) yang terdiri dari tujuh perlakuan dengan empat ulangan. Perlakuan yang diuji antara lain perendaman benih dalam suspensi kompos plus, aplikasi pada lubang tanam, penyemprotan suspensi pada daun semai, kombinasi cara aplikasi tersebut dan kontrol. Inokulasi patogen dan pengamatan perkembangan penyakit dilakukan sama dengan percobaan sebelumnya.

Data yang diperoleh dianalisis secara statistik dengan analisis of varians (ANOVA) menggunakan program SPSS versi 20. Apabila hasil yang diperoleh menunjukkan perbedaan yang nyata maka data dianalisis lebih lanjut dengan menggunakan Uji Jarak Berganda Duncan pada taraf $5 \%$.

\section{HASIL DAN PEMBAHASAN}

Kemampuan Kompos Plus, Kompos dan Jamur Antagonis untuk Meningkatkan Ketahanan Tanaman Tomat terhadap Penyakit Bercak Coklat ( $A$. solani)

Hasil percobaan menunjukkan bahwa kompos plus dapat menekan penyakit bercak coklat pada tanaman tomat sebesar 40,13\% (Tabel 1). Aplikasi kompos plus pada tempat yang berbeda dengan inokulasi patogennya mengindikasikan bahwa penekanan penyakit terjadi karena adanya peningkatan ketahanan tanaman.

Kemampuan kompos plus dalam meningkatkan ketahanan tanaman ini tidak terlepas dari kemampuan komponen-komponen penyusunnya. Kompos plus merupakan kompos yang telah ditambah konsorsium jamur antagonis. Dari hasil percobaan ternyata kompos sendiri juga dapat menekan penyakit bercak coklat dengan tingkat penekanan yang tidak berbeda nyata dengan kompos plus. Kemampuan kompos untuk menginduksi ketahanan tanaman terhadap penyakit memang telah dilaporkan. Zhang et al. (1996) 
melaporkan bahwa kompos yang dicampurkan pada medium tanam dapat menginduksi ketahanan tanaman mentimun terhadap penyakit tular tanah (Phytium spp.) dan juga penyakit tular udara (penyakit antraknosa karena Colletotrichum arbicularea). Kemampuan kompos pada medium tanam untuk menginduksi ketahanan tanaman terhadap penyakit tular udara yang ditunjukkan dengan adanya peningkatan ekspresi dari gen-gen yang terkait dengan PR-proteins juga telah dilaporkan (Vallad et al., 2003; Segarra et al. 2013).

Tabel 1. Pengaruh kompos, kompos plus dan jamur antagonis terhadap penyakit bercak coklat pada tanaman tomat.

\begin{tabular}{lcc}
\hline \multicolumn{1}{c}{ Perlakuan } & $\begin{array}{c}\text { Rata-rata } \\
\text { nilai } \\
\text { AUDPC }\end{array}$ & $\begin{array}{c}\text { Persentase } \\
\text { penekanan } \\
(\%)\end{array}$ \\
\hline Kompos Plus & $27,97 \mathrm{a}$ & 40,13 \\
Kompos & $28,42 \mathrm{a}$ & 39,16 \\
T. Harzianum & $28,38 \mathrm{a}$ & 39,24 \\
Papulaspora sp, & $36,75 \mathrm{~b}$ & 21,32 \\
Paecilomyces sp., & $35,42 \mathrm{ab}$ & 24,17 \\
Campuran suspensi & $40,55 \mathrm{bc}$ & 13,2 \\
jamur & & \\
Kontrol & $46,71 \mathrm{c}$ & - \\
\hline
\end{tabular}

Keterangan: Nilai rata-rata dalam kolom yang diikuti dengan huruf yang sama tidak berbeda nyata menurut Uji jarak Berganda Duncan pada taraf nyata 5\%.

Selain itu, air rendaman kompos atau kompos plus juga diduga dapat memicu ketahanan tanaman. Zhang et al. (1998) melaporkan bahwa air rendaman kompos mampu menginduksi ketahanan tanaman mentimun terhadap $C$. orbicularea yang dicirikan dengan meningkatnya aktifitas patogenrelated (PR) protein seperti enzim $\beta-1,3$ glukanase. Sang \& Kim (2011) juga melaporkan bahwa air rendaman kompos dapat menginduksi ketahanan mentimun dan cabai terhadap antraknosa.

Mikroba yang ditambahkan dalam kompos plus terutama $T$. harzianum juga dapat meningkatkan ketahanan tanaman tomat terhadap penyakit bercak coklat. Walaupun T. harzanum adalah jamur antagonis yang dapat menghambat patogen secara langsung, namun dalam percobaan ini jamur ini tidak kontak langsung dengan patogen sehingga penekanan penyakit kemungkinan besar karena meningkatnya ketahanan tanaman tomat.
Berbagai hasil penelitian telah menunjukkan kemampuan Trichoderma untuk menginduksi ketahanan tanaman. Yedida et al. (2003) melaporkan bahwa $T$. asperellum dapat menginduksi ketahanan tanaman mentimun terhadap penyakit bercak bersudut yang diindikasikan dengan adanya akumulasi fitoalexin dalam jaringan tanaman. Saksirirat et al. (2009) menemukan bahwa Trichoderma sp. dapat menginduksi ketahanan tanaman tomat terhadap beberapa penyakit tular udara yang diindikasikan dengan peningkatan PRprotein seperti enzim kitinase dan $\beta$-1,3-glukanase. Tucci et al. (2011) juga melaporkan bahwa $T$. harzianum mampu menginduksi ketahanan tanaman tomat terhadap penyakit kapang kelabu yang disebabkan Botrytis cinerea.

Efek Cara Aplikasi terhadap Kemampuan Kompos Plus untuk Menekan Penyakit Bercak Coklat ( $A$. solani) pada Tanaman Tomat

Pada percobaan ini ternyata cara aplikasi kompos plus tidak berpengaruh secara nyata pada penekanan peyakit yang dihasilkan. Aplikasi kompos plus dengan salah satu cara yaitu hanya perendaman benih, aplikasi pada medium tanam atau penyemprotan daun semai dapat menekan penyakit bercak coklat sebesar 31-33\%. Ketika semua cara tersebut dikombinasikan, memang penekanan yang dihasilkan cenderung lebih besar yaitu sebesar $42 \%$, namun peningkatan tersebut masih belum signifikan (Tabel 2). Pada penelitian untuk pengendalian penyakit layu fusarium, aplikasi kompos plus pada persemaian dan lubang tanam memberikan efek penekanan penyakit yang lebih baik daripada persemaian saja. Perbedaan efek cara aplikasi tersebut diduga tergantung dari mekanisme pengendalian serta jenis tanaman dan patogen (plant pathosystem) sasaran.

Walaupun cara aplikasi kurang berpengaruh terhadap kemampuan kompos plus untuk meningkatkan ketahanan tanaman, namun dari segi praktisnya kompos plus sebaiknya diaplikasikan pada medium tanam. Hal ini dikarenakan kompos plus ini sebenarnya ditujukan untuk pengendalian penyakit tular tanah. Efek kompos plus terhadap penyakit tular udara ini merupakan nilai tambah. Dengan demikian, kompos plus ini dapat memberikan efek ganda yaitu untuk mengendalikan penyakit tular tanah maupun udara. 
Tabel 2. Efek cara aplikasi terhadap kemampuan kompos plus dalam menekan penyakit bercak coklat pada tanaman tomat.

\begin{tabular}{lcc}
\hline \multicolumn{1}{c}{ Perlakuan } & Nilai rata-rata AUDPC & Penekanan (\%) \\
\hline Perendaman Benih & $29,5 \mathrm{a}$ & 32,0 \\
Aplikasi pada lubanglubang tanam Tanam & $29,1 \mathrm{a}$ & 32,9 \\
Penyemprotan daun semai & $28,7 \mathrm{a}$ & 33,8 \\
Perendaman benih dan aplikasi pada lubang tanam & $27,9 \mathrm{a}$ & 35,7 \\
Aplikasi pada lubang tanam dan penyemprotan daun semai & $27,0 \mathrm{a}$ & 37,7 \\
Gabungan semua cara aplikasi & $25,1 \mathrm{a}$ & 42,1 \\
Kontrol & $43,4 \mathrm{~b}$ & - \\
\hline
\end{tabular}

Keterangan: Nilai rata-rata dalam kolom yang diikuti dengan huruf yang sama tidak berbeda nyata menurut Uji jarak Berganda Duncan pada taraf nyata $5 \%$

Efek Kompos, Kompos Plus dan Jamur Antagonis terhadap Pertumbuhan Tanaman Tomat

Pada penelitian ini, efek kompos plus terhadap pertumbuhan hanya diamati pada saat pembibitan saja sebelum dilakukan inokulasi patogen. Parameter pertumbuhan tanaman yang diamati adalah tinggi tanaman tomat. Aplikasi kompos plus, kompos maupun jamur antagonis dapat memacu pertumbuhan tanaman. Tanaman tomat pada perlakuan tersebut 1,8-2,4 kali lebih tinggi daripada tanaman kontrol. Perlakuan yang mendukung pertumbuhan bibit yang paling baik adalah kompos dan kompos plus (Tabel 3). Kompos memang merupakan pupuk organik yang mengandung berbagai nutrisi yang diperlukan oleh tanaman. Penambahan mikroba pada kompos plus ternyata tidak secara nyata dapat meningkatkan kemampuan kompos dalam mendukung pertumbuhan tanaman. Padahal sebenarnya masingmasing jamur antagonis yang ditambahkan baik secara tunggal maupun gabungannya dapat juga meningkatkan pertumbuhan bibit kubis (Tabel 3).

Tabel 3. Efek kompos, kompos plus, dan mikroba antagonis terhadap pertumbuhan bibit tomat pada 22 hari setelah tanam.

\begin{tabular}{lcc}
\hline Perlakuan & $\begin{array}{c}\text { Rata-rata tinggi bibit } \\
(\mathrm{cm})\end{array}$ & $\begin{array}{c}\text { Peningkatan dibandingkan dengan } \\
\text { kontrol (kali) }\end{array}$ \\
\hline Kompos plus & $8,67 \mathrm{c}$ & 2,4 \\
Kompos & $8,50 \mathrm{c}$ & 2,3 \\
T. harzianum & $6,83 \mathrm{~b}$ & 1,8 \\
Papulaspora sp. & $7,50 \mathrm{bc}$ & 2,0 \\
Paecylomyces sp. & $6,67 \mathrm{~b}$ & 1,8 \\
Campuran ketiga jamur antagonis & $6,83 \mathrm{~b}$ & 1,8 \\
Kontrol & $3,67 \mathrm{a}$ & 1,0 \\
\hline Keterangan: Nilai rata-rata dalam kolom yang diikuti dengan huruf yang sama tidak berbeda nyata menurut Uji jarak Berganda \\
\multicolumn{2}{c}{ Duncan pada taraf nyata 5\%. }
\end{tabular}

Dari hasil penelitian ini secara keseluruhan menunjukkan bahwa kompos plus maupun kompos dapat meningkatkan ketahanan tanaman tomat terhadap penyakit bercak coklat. Pada penelitian ini, penambahan mikroba antagonis ke dalam kompos ternyata belum dapat meningkatkan kemampuan kompos dalam meningkatkan ketahanan tanaman. Namun demikian, efek ini akan berbeda apabila digunakan untuk pengendalian penyakit secara langsung misalmya untuk penyakit tular tanah. Pada penelitian sebelumnya, penambahan mikroba antagonis ke dalam kompos (yang disebut dengan kompos plus) memang dapat menekan penyakit tular tanah seperti rebah kecambah lebih baik daripada kompos biasa (Istifadah dkk., 2007; 2008).

Pada penelitian lain, penambahan mikroba antagonis ke dalam kompos juga dapat meningkatkan efek pengendalian yang dihasilkan. Penambahan jamur antagonis Trichoderma asperellum (Trillas et al., 2004) atau T. harzianum (Pugliese et al., 2011; El-Mohameddy et al., 2012; Faruk et al. 2014) ke dalam kompos dapat meningkat 
efek pengendalian terhadap penyakit damping off pada berbagai tanaman (Pugliese et al., 2011; Trillas et al., 2004; Faruk et al. 2014) dan busuk kering pada kentang (El-Mohamedy et al., 2012). Walaupun secara umum memang penambahan mikroba antagonis ke dalam kompos dapat meningkatkan efek pengendalian, namun demikian pada beberapa kasus penambahan mikroba antagonis tidak dapat meningkatkan keefektifan pengendalian. Hal tersebut tergantung dari jenis bahan organik dan juga jenis patogen dan tanaman (plant pathosystem) sasaran (Postma et al., 2003; Pugliese et al., 2011).

Sebenarnya kompos plus ini digunakan untuk mengendalikan penyakit tular tanah. Namun demikian, aplikasi kompos plus ternyata juga dapat meningkatkan ketahanan tanaman terhadap penyakit tular udara. Walaupun sebenarnya penekanan penyakit tular udara yang dihasilkannya hanya sebesar $40 \%$, namun dengan integrasi dengan cara pengendalian ramah lingkungan yang lain misalnya dengan cara aplikasi air rendaman kompos plus pada daun secara regular, penggunaan tanaman tahan, serta cara pengendalian kultur teknis yang lain maka efek pengendalian dapat ditingkatkan.

\section{SIMPULAN DAN SARAN}

\section{Simpulan} bahwa:

Dari hasil percobaan dapat disimpulkan

1. Kompos plus, kompos, dan T. harzianum dapat meningkatkan ketahanan tanaman sehingga dapat menekan penyakit bercak coklat sebesar $39,2 \%-40,1 \%$.

2. Cara aplikasi kompos plus tidak berpengaruh secara nyata terhadap kemampuannya dalam menekan penyakit. Aplikasi kompos plus dengan cara perendaman benih dalam air rendaman kompos plus, aplikasi pada lubang tanam atau penyemprotan dengan air rendaman kompos baik secara tunggal maupun dengan cara gabungan dapat menekan penyakit bercak coklat sebesar $31,96 \%-42,08 \%$

\section{Saran}

Kompos plus dapat digunakan untuk pengendalian penyakit tular tanah maupun udara. Guna meningkatkan efek pengendaliannya terhadap penyakit tular udara, maka cara pengendalian ini perlu digabungkan dengan cara pengendalian lain yang kompatibel.

\section{DAFTAR PUSTAKA}

Aviles, M, C Borrero, and MI Trillas. 2011. Review on compost as inducer of disease suppressive in plant in soiless culture. Dyn. Soil Dyn. Plant. 5:1-11.

Campbell, LC, and VL Madden. 1990. Introduction Plant Disease Epidemiology. John Wiley and Son, USA. $532 \mathrm{p}$.

El-Mohamedy, RSR, M.M. Abdel-Kader, F. Abd-ElKareem, M.A. Abd-Allah, N.S. El-Mougy, NG El-Gamal, and YO Fatouh. 2012. Field application of bio compost to control Fusarium dry rot disease of potato in newly Reclaimed lands. Journal of Agricultural Technology. 8:1375-1387.

Faruk, MI, ML Rahman, MN Islam, MM Rahman, and MA Rahman. 2014. Management of chickpea seedling diseases through soil amendment with tricho-compost. Int. J. Phytopathol. 3(2):73-79.

Hoitink, HAJ, LV Madded, and MJ Boehm. 1996. Relationship among organik matter decomposition level, microbial species diversity and soil borne disease severity. Pp. 237-249 in Principles and Practices of Managing Soil Borne Plant Pathogens ( $\mathrm{R}$ Hall, Ed.). APS Press, Minnesota.

Istifadah, N, T Sunarto, and D Herdiyantoro. 2007. Pengembangan Formulasi Campuran Antagonis dalam Bahan Organik untuk Pengendalian Penyakit pada Tanaman Tomat. Laporan Penelitian Andalan Universitas Padjadjaran. Lembaga Penelitian dan Pengabdian kepada Masyarakat, Universitas Padjadjaran, Bandung.

Istifadah, $\mathrm{N}, \mathrm{T}$ Sunarto, $\mathrm{D}$ Kartiwa, dan $\mathrm{D}$ Herdiyantoro,. 2008. Kemampuan kompos plus dalam menekan penyakit layu fusaium (Fusarium oxysporum f.sp. lycopersici) pada tanaman tomat. J. Agric.Sc. 19:60-65.

Noble, R, and E Conventry. 2005. Supression of soilborne plant disease with compost: A review. Biocontrol Science and Technology. 15:3-20.

Postma, J, M Montanari, and PHJF Van denBoogert. 2003. Microbial enrichment to enhance the disease suppressive activity of compost. Eur. J. Soil Biol. 39: 157-163.

Pugliese, M, BP Liu, ML Gullino and A Garibaldi. Microbial enrichment of compost with biological control agents to enhance 
suppressiveness to four soil-borne diseases in greenhouse. Journal of Plant Diseases and Protection 118 (2): 45-50.

Saksirirat, W, P Chareerak, and W Bunyatrachata. 2009. Induced systemic resistance of biocontrol fungus, Trichoderma spp. against bacterial and gray leaf spot in tomatoes. J Food Ag-Ind. Special Issue, 99-104.

Sang MK, and KD Kim. 2011. Biocontrol activity and primed systemic resistance by compost water extract against antrachnose of pepper and cucumber. Phytopathology. 101:732740 .

Scheuerell, S, and W Mahaffee. 2002. Compost tea: principles and prospects for plant disease control. Compost Science and Utilization. 10: 313-338.

Segarra G, G Santpere, G Elena, and I Trillas. 2013. Enhanced Botrytis cinerea resistance of arabidopsis plants grown in compost may be explained by increased expression of defense-related genes, as revealed by microarray analysis. PLoS ONE 8(2): e56075. doi:10.1371/journal.pone.0056075.

Semangun, H. 2007. Penyakit-penyakit Tanaman Hortikultura di Indonesia, Edisi Ke-2. Gadjah Mada University Press, Yogyakarta.

St. Martin, CCG, and RAI Brathwaite. 2012. Compost and compost tea: principles and prospects as substrates and soil-borne disease management strategies in soil-less vegetable production. Biol. Agric. Hortic. 28:1-33.

Trillas, MI, E Casanova, D Sant, JC Tello, J Ordovás, C Borrero, and M Avilés. 2004. Composts and enriched composts as alternatives to chemicals in plant disease control.
Proceeding of International Conference Soil and Compost Eco-Biology: 17-6.

Trillas, MI, E Casanova, L Cotxarrera, J Ordovás, C Borrero, and M Avilés. 2006. Composts from agricultural waste and the Trichoderma asperellum strain T-34 suppress Rhizoctonia solani in cucumber seedlings. Biological Control. 39: 32-38.

Tucci, M, M Ruocco, LD Masi, M de Palma, and M Lorito. 2011. The beneficial effect of Trichoderma spp. on tomato is modulated by the plant genotype. Molecular Plant Pathology 12 (4): 341-354.

Vallad, GE, L Cooperbandb, and RM Goodmana. 2003. Plant foliar disease suppression mediated by composted forms of paper mill residuals exhibits molecular features of induced resistance. Physiol. Mol. Plant P. 63: 65-77.

Yedidia, I, M Shoresh, Z Kerem, N Benhamou, Y Kapulnik, and I Chet. 2003. Concomitant induction of systemic resistance to Pseudomonas syringae pv. lachrymans in cucumber by Trichoderma asperellum (T203) and accumulation of Phytoalexins. Applied and Environmental Microbiology. 69:7343-7353.

Zhang, W, WA Dick, and HAJ Hoitink. 1996. Compost-Induced systemic acquired resistance in cucumber to pythium root and antracnose. Phytopathology. 86(10):10661070.

Zhang, W, DY Han, WA Dick, KR Davis, and HAJ Hoitink. 1998. Compost and compost water extract-induced systemic acquired resistance in cucumber and arabidopsis. Phytopathology. 88:450-455. 